Vietnam Academy of Science and Technology
Vietnam Journal of Earth Sciences
http://www.vjs.ac.vn/index.php/jse

\title{
Surface sediment grain-size distribution and sediment transport in the subaqueous Mekong Delta, Vietnam
}

Nguyen Trung Thanh*1, Karl Stattegger2, Daniel Unverricht², Charles Nittrouer ${ }^{3}$, Phung Van

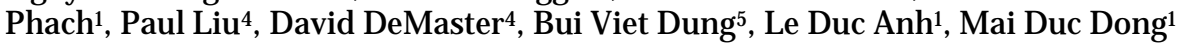

${ }^{1}$ Institute of Marine Geology and Geophysics, VAST, Vietnam

${ }^{2}$ University of Kiel, Germany

${ }^{3}$ School of Oceanography, University of Washington, Seattle, WA, USA

${ }^{4}$ North Carolina State University, USA

${ }^{5}$ Institute of Petroleum, Vietnam

Received 14 February 2017. Accepted 25 May 2017

\begin{abstract}
The sediment transport around the Mekong delta was clarified by using geochemical data and modeling indicating the southwestward transport of re-suspended sediments under the influence of NE monsoon. However, the detail pattern of grain-size distribution of the surface sediments in the subaqueous Mekong River delta has not been well understood. This paper presents characteristics of grain-size parameters of the surface sediments in order to interpret the sediment-transport pattern and the linkage to coastal erosion and deposition off the Mekong River delta. Surface sediments collected in the coastal water of Mekong River delta (as far south as Ca Mau Peninsula) were analyzed to determine the grain-size distribution and sediment transports in subaqueous Mekong delta. Results indicated that the net sediment transport was southwestward to the $\mathrm{Ca}$ Mau peninsula and the sediments were finer from the delta topset downward the delta foreset. In contrast, the sediment particles on the adjacent inner shelf were coarser and are more poorly sorted due to the increase in carbonate shell fragments and the Early Holocene sediments. The sediment grainsize parameters were variable in different sedimentary sub-environments of the subaqueous Mekong delta and controlled by the distance of sediment transport, the hydrodynamic regime of each region and coastal erosion of the delta coast.
\end{abstract}

Keywords: Mekong River delta, subaqueous delta, grain-size parameters.

(C)2017 Vietnam Academy of Science and Technology

\section{Introduction}

The formation of the Mekong River delta was suggested to initiate at $\sim 8000 \mathrm{yr}$ BP in Phnom Penh, Cambodia because the rate of

"Corresponding author, Email: ntthanh@imgg.vast.vn the Holocene sea level rise decreased (Tamuara et al., 2009). The progradation of the Mekong River delta has led to form a great flat plain of $\sim 62,520 \mathrm{~km}^{2}$ during the regression of relative sea level over the last 4550 yr BP (Nguyen et al., 2000), after the 
Nguyen Trung Thanh, et al./Vietnam Journal of Earth Sciences 39 (2017)

maximum highstand sea level was reached at $\sim 2.0-2.5 \mathrm{~m}$ above the present sea level (Stattegger et al., 2013). The Mekong River delta was changed from tide-dominated delta to tide-wave-dominated delta during the Late Holocene (Ta et al., 2002a), and the delta coast has migrated $\sim 200 \mathrm{~km}$ seaward since 8000 yr BP (Tamuara et al 2007 and 2009). The rapid progradation of the delta system at a rate of $26 \mathrm{~m} / \mathrm{yr}$ around the $\mathrm{Ca}$ Mau Cape ( $200 \mathrm{~km}$ downstream from the Mekong River mouths) demonstrates that the wave influence has caused resuspended sediments to be bypassed into the Gulf of Thailand by the longshore current (Xue et al., 2010).

The subaqueous formation of the Mekong River delta was separated from the underlying Early Holocene transgressive sediments by the maximum flooding surface (Dung et al., 2013; Thanh et al., 2014). Numerous incised valleys of Paleo-Mekong River on the adjacent shelf were infilled with sediments during the transgression that followed the last glacial maximum (Dung et al., 2013; Tjallingii et al., 2010, Thanh et al., 2014). Shelf studies indicate the sea level rose quickly in the period of 13.000 to 9,000 yr BP (Tjalingii et al., 2010) causing rapid flooding on the shelf. The sediment transport in the region has been studied using morphological characteristics of sand waves (Kubiski, 2008; Dung et al., 2009). These results indicated that northeast monsoon highly influenced the sand-wave morphology and their movement. The sedimentary deposition and geomorphological characteristics of the subaqueous Mekong River delta revealed a very high rate of sediment accumulation around the $\mathrm{Ca}$ Mau Peninsula (Xue et al., 2010; Unverricht et al., 2013). The sediment transport around the Mekong delta was successfully clarified using geochemical data and modeling that indicated the southwestward transport of re-suspended sediments under the influence of NE monsoon (Xue et al., 2010; 2011). However, the detailed grain-size distribution pattern of the surface sediments in the subaqueous Mekong River delta has not been well understood. This paper presents characteristics of grain-size parameters of the surface sediments in order to interpret the sediment-transport pattern and the linkage to coastal erosion and deposition off the Mekong River delta.

\section{Regional setting}

The Mekong River originates from southeastern Tibetan Plateau and flows through six countries, consisting of China, Myanmar, Laos, Thailand, Cambodia and Vietnam prior to discharge into the East Sea. The river runs across $\sim 4350 \mathrm{~km}$ in length and catchment area is of $\sim 795,000 \mathrm{~km}^{2}$, ranking as the $10^{\text {th }}$ of among the largest catchment in the world (Liu et al., 2009), the $7^{\text {th }}$ in water discharge $(\sim 470$ $\left.\mathrm{km}^{3} / \mathrm{yr}\right)$ and the $11^{\text {th }}$ in sediment discharge $\left(\sim 160 \times 10^{6}\right.$ tons/yr) (Milliman and Meade, 1983; Milliman and Syvitski, 1992). River discharge was $\sim 144 \pm 36$ tons/yr, being lightly unchanged during the last three thousand years (Ta et al., 2002b). The Mekong River subdivides into two major distributaries that are called Tien and Hau River within the Vietnam territory. The Tien River flows into the East Sea through six river mouths: Cung Hau, Co Chien, Ham Luong, Ba Lai, Cua Dai and Cua Tieu. The Hau River flows into the East Sea through two river mouths: Dinh An and Tran De.

Sediment discharge of the Mekong River was recently estimated to be $\sim 110$ tons/yr based on hydrological and sediment dynamics in the lowermost part of the tidal-influenced Hau distributary (Nowacki et al., 2015). Seaward sediment export occurred during high flow and landward sediment import occurred during low flow due to the tidal and estuarine influence (Nowacki et al., 2015; Wolanski et al., 1996; 1998). Sediments deposited on the Hau River bed was coarser during high flow and finer during low flow (Nowacki et al., 2015), indicating the export of sand to the sea 
Vietnam Journal of Earth Sciences, 39(3), 193-209

during the high-flow season of the southwest monsoon.

The study area is the subaqueous Mekong River delta, extending down to $\sim 20-25 \mathrm{~m}$ of water depth (Figure 1). The hydrodynamics of the study area is driven by tide, river flow and monsoon conditions. The tide in the region is characterized by semidiurnal amplitude of 3-4 $\mathrm{m}$ in height in the Mekong river mouths and decreases to $2 \mathrm{~m}$ in height in the Ca Mau Peninsula. The river flow is high from August to October annually. The monsoon consists of northeast winter monsoon (November to April), blows from the North and the Northeast at an average speed of $8 \mathrm{~m} / \mathrm{s}$ while the Summer monsoon blows from the South and the Southwest at an average speed of $6 \mathrm{~m} / \mathrm{s}$ (Ninh 2003; Dung et al., 2009).

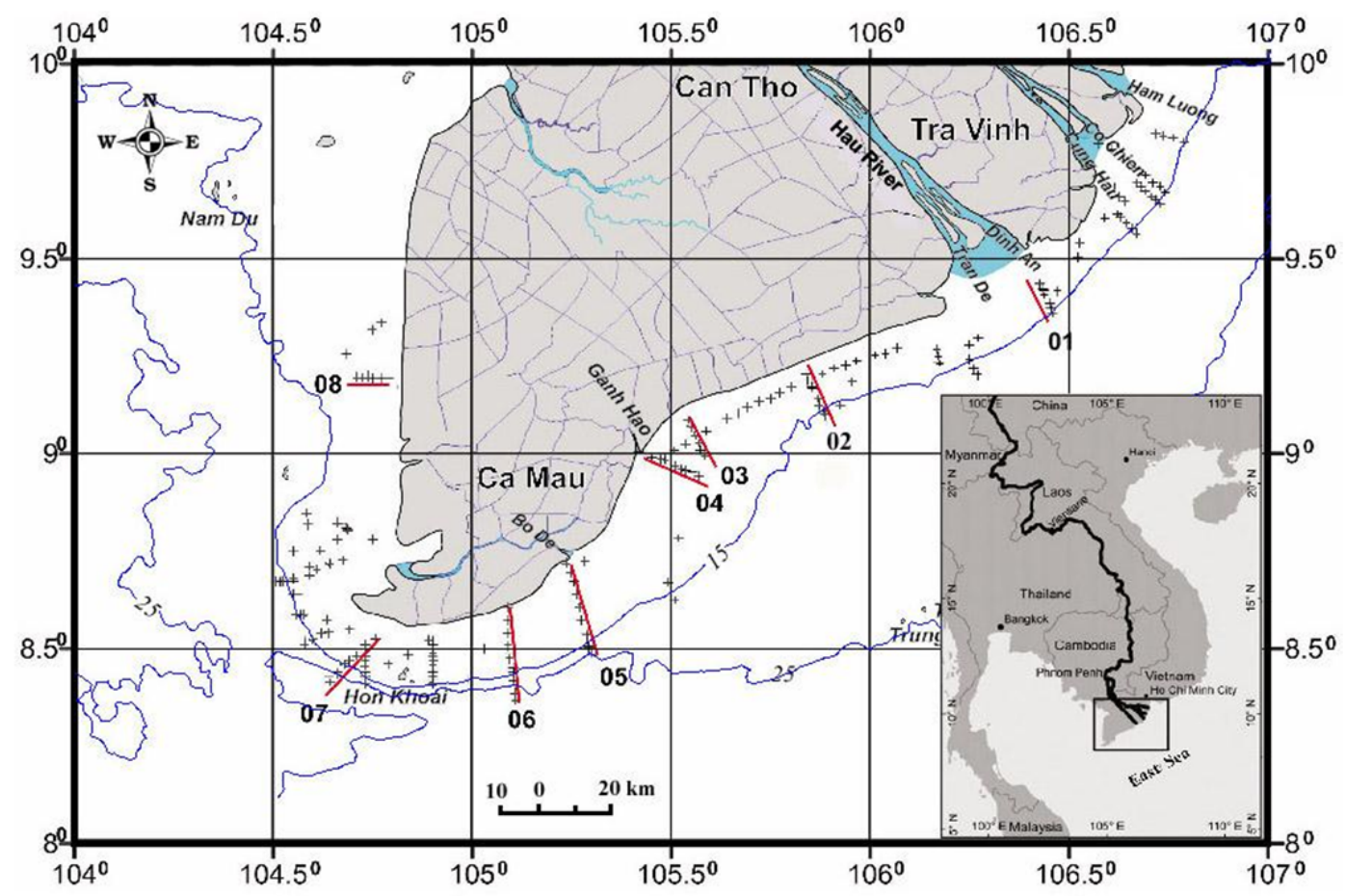

Figure 1. Location of the study area and sampling sites

The Holocene sediments unconformably overlie on the late undivided Pleistocene facies (Ta et al., 2002a). The change of Holocene sediment facies reflected a rapid sea-level rise since the last glacial episode (Ta et al., 2001). The Holocene formation consists of incised valley infilling and overlying deltaic sediments. The incised valley infilling sediments range from estuarine channel/tidal river sandy silt, muddy tidal flat/salt marsh, to estuarine sand and finally to the open bay muddy facies (Ta et al., 2001; 2002a). The deltaic sediments have been formed since around $5.3 \mathrm{cal} \mathrm{ka} . \mathrm{BP}$ in association with the decrease of sea level (Ta et al., 2001). The deltaic facies includes bottom set, foreset, sub- to intertidal flat, foreshore, beach ridge/marsh and finally deltaflood plain (Ta et al., 2002a).

\section{Available data and methodology}

In the present study, 238 surface sediment samples were collected in coastal waters from Co Chien River mouth to the Ca Mau Peninsula (Figure 1). Surface sediment samples (0- 
Nguyen Trung Thanh, et al./Vietnam Journal of Earth Sciences 39 (2017)

$5 \mathrm{~cm}$ ) were taken using the grab samplers during three field trips in April of 2007, 2008 and 2014. Eight seismic profiles were measured using the Boomer systems in 2007 and 2008 and used to support the interpretation of the variation of sediment characteristics on the cross-shelf transects.

The sediment grain size analysis was undertaken for all samples, and 14 of total 238 samples were selected for carbonate and total organic carbon (TOC) analysis. The sediment grain sizes were analyzed using a Mastersizer 2000 laser analyzer at the University of Christian-Albrechts in Germany and the LS Particle Size Analyzer at the Institute of Constructed Materials in Vietnam. Grain-size parameters (in metric units) were calculated. Mean was calculated in equation (1) followed the method of Blott and Pye (2001) that is modified from the method of Folk and Ward (1957). Other grain-size parameters were calculated from the cumulative curve as $d_{90}, d_{75}, d_{50}, d_{25}$ and $\mathrm{d}_{10}$ (Figure 2). Mode of grain size particles was calculated from distribution curves (Figure 2). In this study, box plots were used to present the grain size parameters $\left(\mathrm{d}_{90}, \mathrm{~d}_{75}\right.$, $\mathrm{d}_{50}, \mathrm{~d}_{25}, \mathrm{~d}_{10}$, mean, modes) across the eight transects in the subaqueous Mekong delta.

$$
\text { Mean }=\exp \frac{\ln d_{16}+\operatorname{lnd}_{50}+\operatorname{lnd}_{84}}{3}
$$

Where $d_{16}, d_{50}$ and $d_{84}$ were calculated from the graphic accumulative curve. (a)

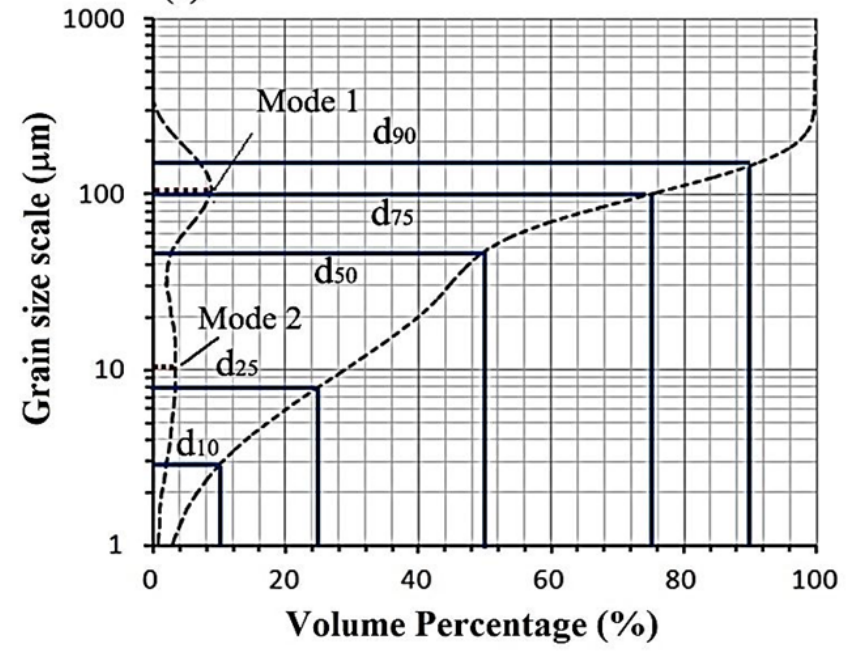

(b)

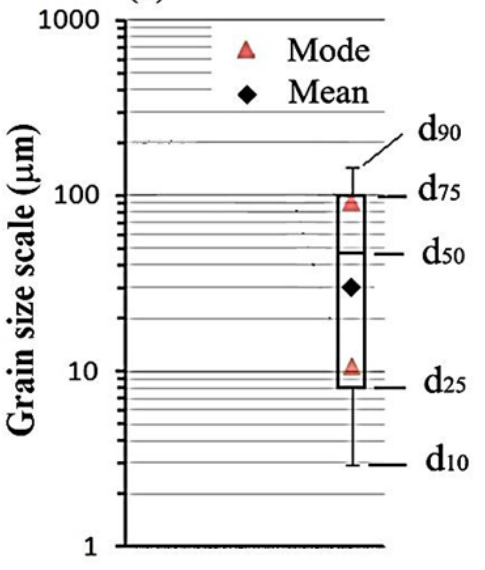

Figure 2. (a) Distribution curve and cumulative curve of the sample DA-7 and (b) a box plot shows the grain size parameters (d90, d75, d50, d25, d10, mean, modes)

We can subsequently compare the grainsize parameters of sediment samples along each transect and define the sediment sorting degree, skewness, grain size distribution pattern through the box plots. The well-sorted sediment sample has quite similar mean, mode and median values, unimode and a narrower box plot (e.g., the sample DA-2 in
Figure 3). In contrast, the poorly sorted sediment sample has significantly difference in mean, mode and median values, multiple modes and a wider box plot (e.g., the sample DA-7 in Figure 3).

The grain-size parameters (d50, mean, mode 1), mode number and the fraction of sand were used for interpolation. The results 
Vietnam Journal of Earth Sciences, 39(3), 193-209

from 16 sediment samples collected from the adjacent shelf showed the strong influence by multiple sources of marine shell fragments and Holocene relict sediments that can cause the serious error, and therefore, they were not used for interpolation. Then inatural-neighbor interpolation method introduced by Sibson (1981) together with the anisotropy parameters (radius $=1.4$ and angle $=600$ ) were used to generate thematic maps to perform the tendency of grain-size parameter distributions by the basic equation as follow:

$$
\mathrm{G}(\mathrm{x}, \mathrm{y})=\sum_{i=1}^{N} w_{i} f\left(x_{i} y_{i}\right)
$$

Where $G(x, y)$ is the estimate at the target point $(\mathrm{x}, \mathrm{y})$ from the measured values $\mathrm{f}\left(\mathrm{x}_{\mathrm{i}}, \mathrm{y}_{\mathrm{i}}\right)$, $\mathrm{i}$ $=1,2, \ldots, \mathrm{N}$ at points $\left(\mathrm{x}_{\mathrm{i}}, \mathrm{y}_{\mathrm{i}}\right)$; and $\mathrm{w}_{\mathrm{i}}$ are the weights.

TOC and carbonate contents were analyzed using a CHN-O Elemental Analyser of Carlo Erba Instruments in the Institute of Marine Biogeochemistry at Hamburg University. (a)

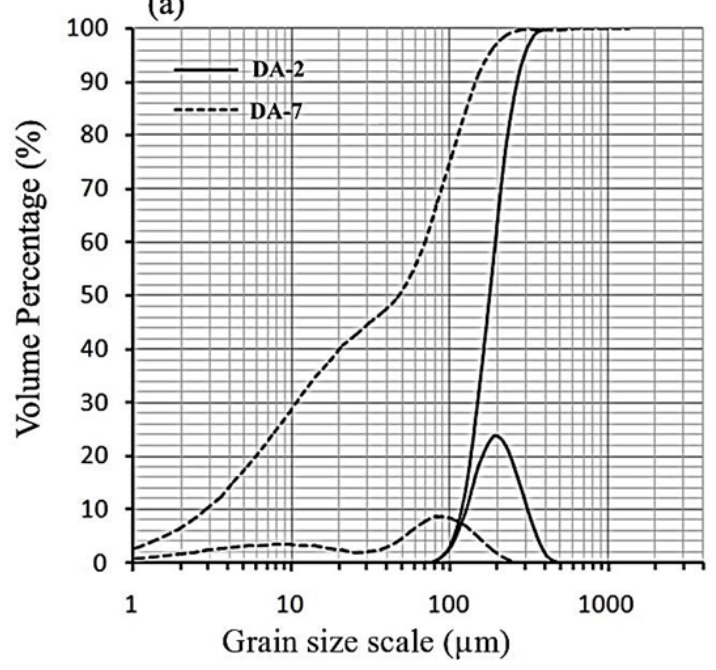

(b)

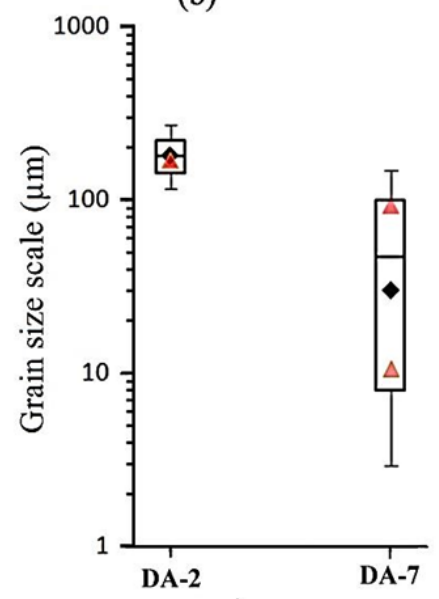

Figure 3. Diagram (a) showing the grain-size characteristics through cumulative curve and distribution curve; Diagram (b) showing the grain-size characteristics through box plots

Sediment samples were dried, crushed and placed into two silver cartridges and weighed. One received $10 \% \mathrm{HCl}$ to entirely dissolve the carbonate fraction of the sediment. The samples were then burned at $1021{ }^{\circ} \mathrm{C}$ to generate $\mathrm{CO}_{2}$-gas in a thermal conductivity detection unit for measuring TOC. Acetanilid was used as a standard. In a second procedure using another tin cartridge without added $\mathrm{HCl}$ was analyzed for the total carbon (TC). Then the carbonate content was calculated following the equation (3), assuming that all the carbonate was present as calcite or aragonite. In this study, carbonate content and TOC were used to support the interpretation of granulometric characteristics of sediments and evaluation of the influence of terrigenous sediments from the Mekong River system.

$$
\mathrm{CaCO}_{3}(\%)=(\mathrm{TC}-\mathrm{TOC}) \times 8.33
$$

\section{Results and Discussion}

Sedimentary characteristics of surface sediments in each transect:

Transect 01 (Figure 4) revealed well sorted sand on the subaqueous delta topset, indicating energetic hydrodynamics (waves, currents). The muddy sediment on the subaqueous delta foreset was finer down the delta 
slope in general. The grain-size parameters of fine sediment on the delta slope reflected low impacts of hydrodynamic regimes (wave and currents).
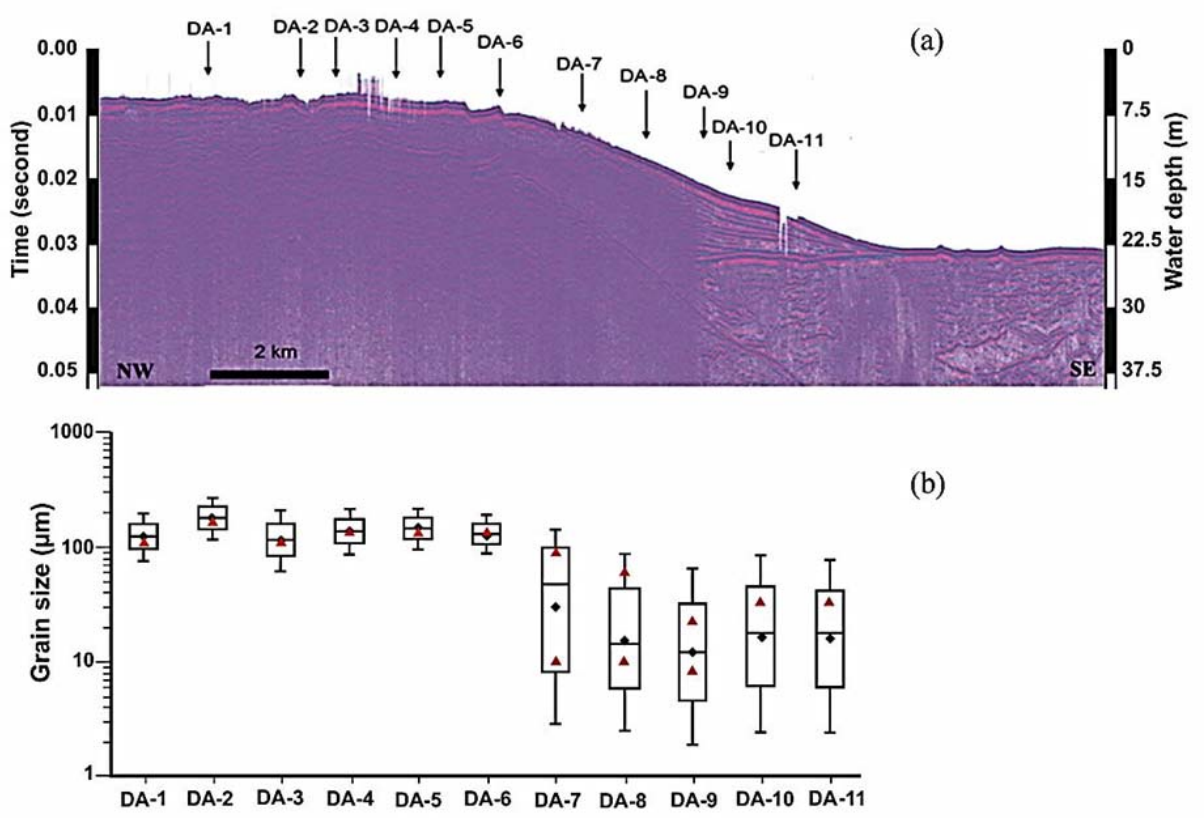

(b)

Figure 4. Variation of grain-size parameters along transect 01

Transect 02 was located southward of the Tran De River mouth, a portion of the subaqueous delta with thin Holocene sediment thickness (Dung et al., 2013). The delta slope approaches near the coast with a gentle gradient in comparison to the transect 01 . All surface sediment samples were collected on the delta foreset and the adjacent shelf (Figure 5). In general, the sediment was slightly finer down the foreset, and revealed a single mode of grain distribution, suggesting a simple source of the sediment. Samples on the adjacent shelf demonstrated two or three distinctive modes of the sediment distribution (Figure 5). On this transect, five samples were selected for analysis on carbonate and TOC contents. The coarser sediments on the adjacent shelf contained shell fragments that were high carbonate content (>25\%) (Figure 5, Table 1). Two or three distinctive modes suggested multiple sediment sources: one from the
Mekong River (5-8 $\mu \mathrm{m})$, and the others come from early Holocene relict sediments and carbonate shell fragments. TOC in sediments from the adjacent inner shelf was lower than that from the delta foreset (Figure 5, Table 1). This evidence indicated the small influence of terrigenous sediment from Mekong River to the adjacent shelf.

Transect 03 was located at adjacent to the Ganh Hao River mouth and had a complicated variation of grain-size parameters due to morphological complexity of the delta foreset profile. Two successions of sediment deposits were observed through the seismic profile (Figure 6). The grain-size parameters varied irregularly, partially indicating their relationship to stratigraphic complications. The sediments were finer downwards on each delta succession. The sediments in the transitional part from the first succession to the second succession or from the second succession to the adjacent shelf were characterized by two 
Vietnam Journal of Earth Sciences, 39(3), 193-209

distribution modes; one mode showed very fine sand $(114 \mu \mathrm{m})$ while the other mode was close to fine silt $(5-8 \mu \mathrm{m})$. The distribution modes could be generated by a combination of bedload and suspended particle transport from the Mekong River or a mixing of two sediment sources. These granulometric characteristics indicated that a considerable amount of sand had been transported seaward from the coast and deposited on the foreset. The largest modes of three sediment samples (GH-9, GH-10, GH-11) showed a wide size range from 138-169 $\mu \mathrm{m}$, reflecting a contribution of carbonate shell fragments and relict Holocene sediments . The geochemical results indicated that TOC was $<1 \%$ and the carbonate content was higher for the samples located seaward (Figure 6, Table 1).
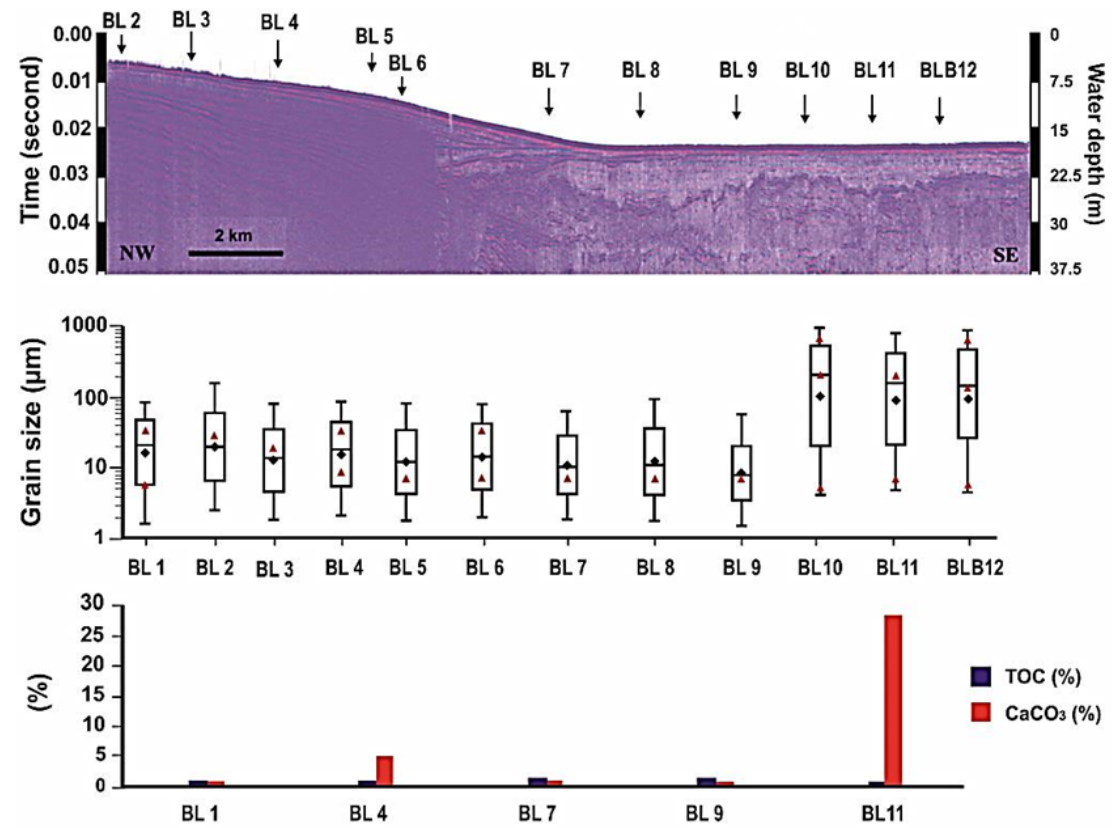

Figure 5. Variation of grain-size parameters and carbonate, TOC along transect 02

Table 1. List of samples for TOC and carbonate analysis and analytical results

\begin{tabular}{lcccc}
\hline Sample Name & Longtitude & Latitude & TOC [\%] & $\mathrm{CaCO}_{3}[\%]$ \\
\cline { 2 - 4 } \cline { 3 - 4 } BL-1 & 105.837 & 9.218 & 0.693 & 0.562 \\
BL-2 & 105.843 & 9.188 & 0.725 & 4.855 \\
BL-3 & 105.871 & 9.142 & 1.010 & 0.714 \\
BL-4 & 105.883 & 9.109 & 1.018 & 0.281 \\
BL-5 & 105.892 & 9.084 & 0.316 & 28.166 \\
GH -4 & 105.557 & 9.040 & 0.884 & 1.075 \\
GH-6 & 105.573 & 9.010 & 0.356 & 1.199 \\
GH-9 & 105.600 & 8.969 & 0.515 & 12.144 \\
GH -11 & 105.609 & 8.939 & 0.409 & 11.675 \\
BD-1 & 105.110 & 8.369 & 0.349 & 20.059 \\
BD-6 & 105.105 & 8.418 & 0.707 & 6.857 \\
BD-10 & 105.102 & 8.451 & 0.173 & 5.022 \\
BD-15 & 105.090 & 8.539 & 0.793 & 2.511 \\
BD-17 & 105.090 & 8.607 & 0.987 & 1.489 \\
\hline
\end{tabular}


Nguyen Trung Thanh, et al./Vietnam Journal of Earth Sciences 39 (2017)
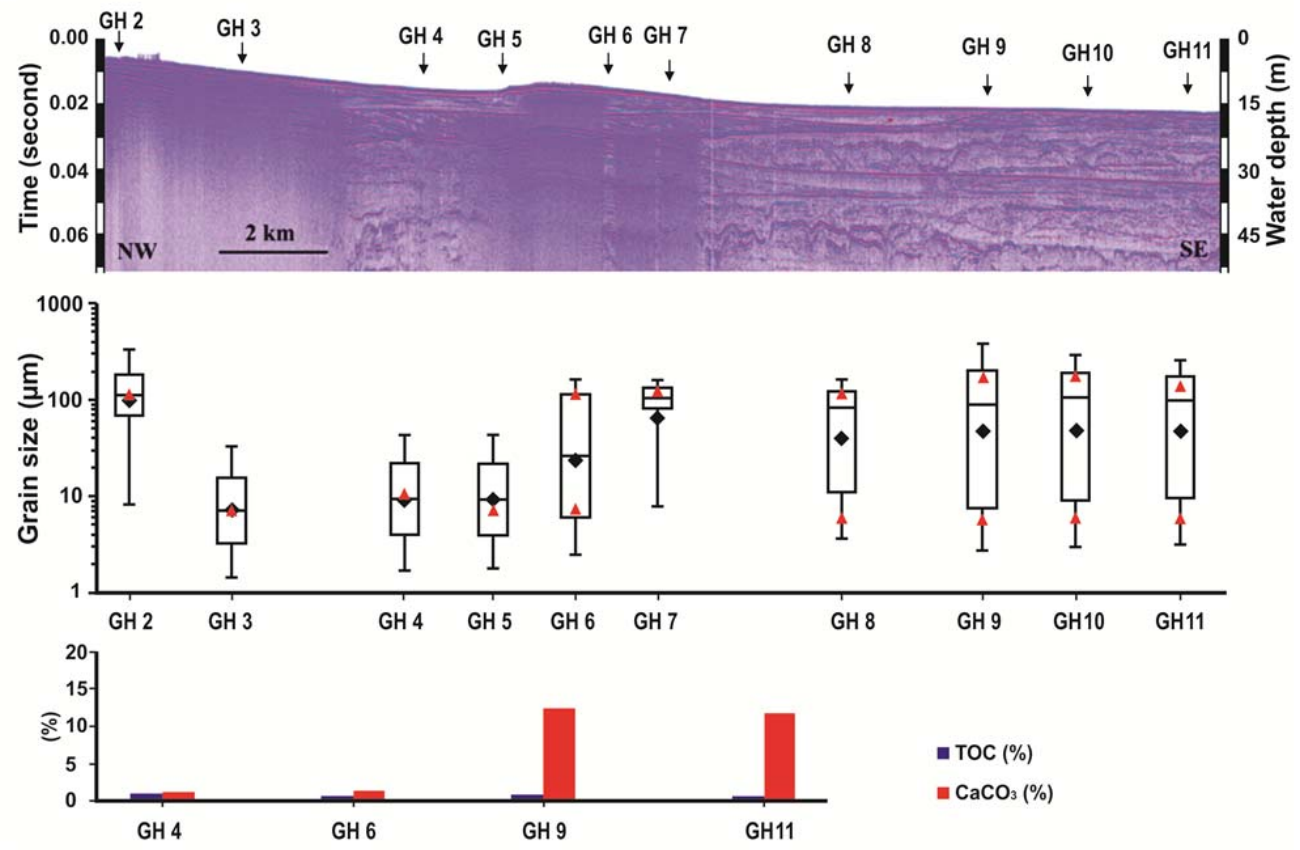

Figure 6. Variation of grain-size parameters and carbonate, TOC contents along transect 03

Transect 04 was located adjacent to the transect 03, crossed the subaqueous delta from the Ganh Hao River mouth. A sandy top layer was observed to overly the foreset strata (Figure 7). The distribution of a well sorted sandy layer demonstrated the intensification of the hydrodynamic regime. The sandy sediments characterized by unimodal distribution; very fine sand mode $(114 \mu \mathrm{m})$, being similar to the transect 03 . The presence of this sand layer indicated that a considerable amount of very fine sand could be transported seaward from the coast to the delta slope (around Ganh Hao River mouth) due to coastal erosion of this area.

Transect 05 was located across the subaqueous delta southeastward of the $\mathrm{Ca} \mathrm{Mau}$ Peninsula from Bo De River mouth. The bathymetric configuration of the transect 05 revealed sand ridges run parallel to the shoreline (Figure 8).
The variation in sediment grain size parameters depends on the bathymetric configuration. The sandy silt was found near the coast and in the depressions. Silty sand and sand deposits scattered on the upper part of the ridges. The sediments on the upper parts of sand ridges and in depressions demonstrated a distribution mode of very fine sand $(114 \mu \mathrm{m})$ and fine silt $(5-8 \mu \mathrm{m})$ respectively. The sediments on the transition from the lower parts to the upper parts were distinguished by biomodal distribution: one was very fine sand and another was fine silt. In addition, the sediment on the adjacent shelf surface showed two or three distribution modes. The most coarse mode $(>500 \mu \mathrm{m})$ was distinctly larger than the sandy mode found closely to shore.

Transect 06 was located southeastward of the Ca Mau Peninsula towards the Hon Khoai Island. The morphology of the transect 06 was similar to the transect 05 (Figure 9), including sand ridges. The grain-size variation of this 
Vietnam Journal of Earth Sciences, 39(3), 193-209

transect is quite similar to that of the transect adjacent shelf in comparison to other samples 06 . TOC was $<1 \%$ and carbonate content was located landward on the subaqueous delta significantly higher in the sample HK-1 on the (Figure 9, Table 1).
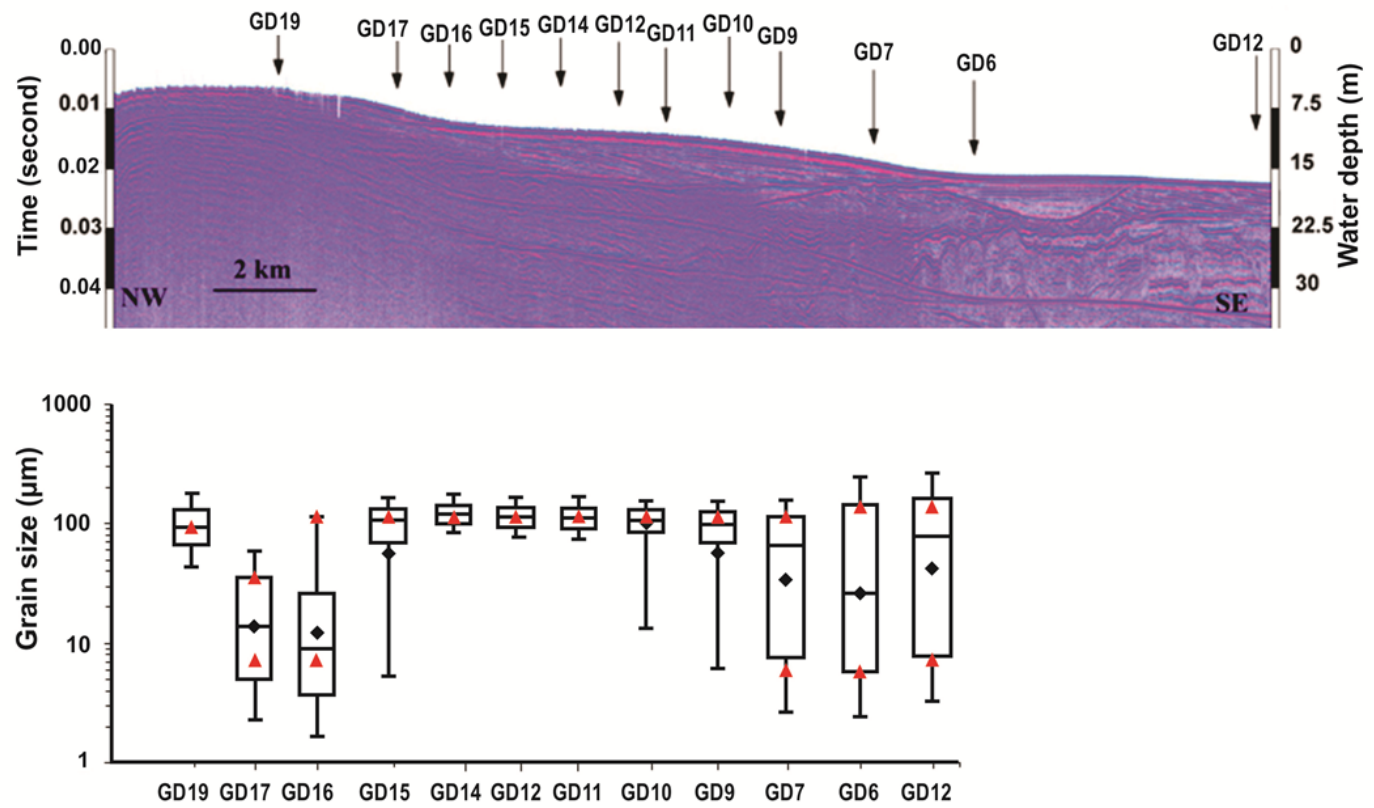

Figure 7. Variation of grain-size parameters along transect 04
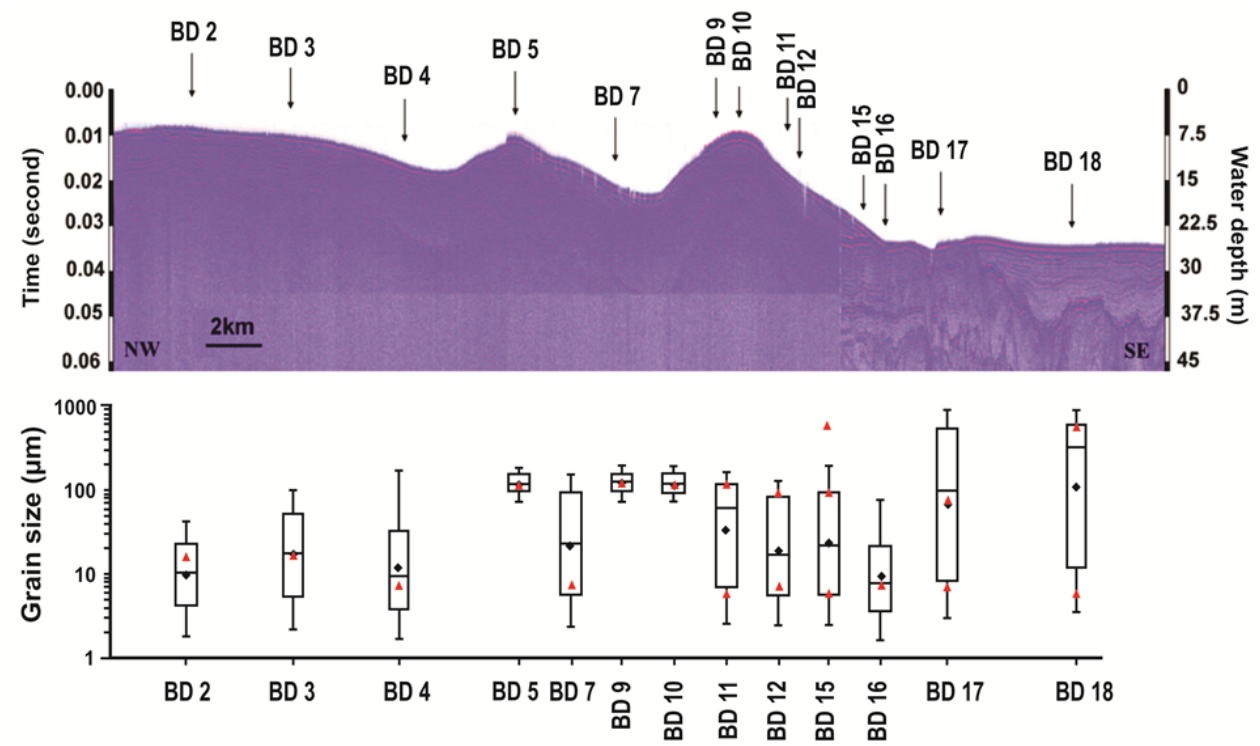

Figure 8. Variation of grain-size parameters along transect 05 
Nguyen Trung Thanh, et al./Vietnam Journal of Earth Sciences 39 (2017)

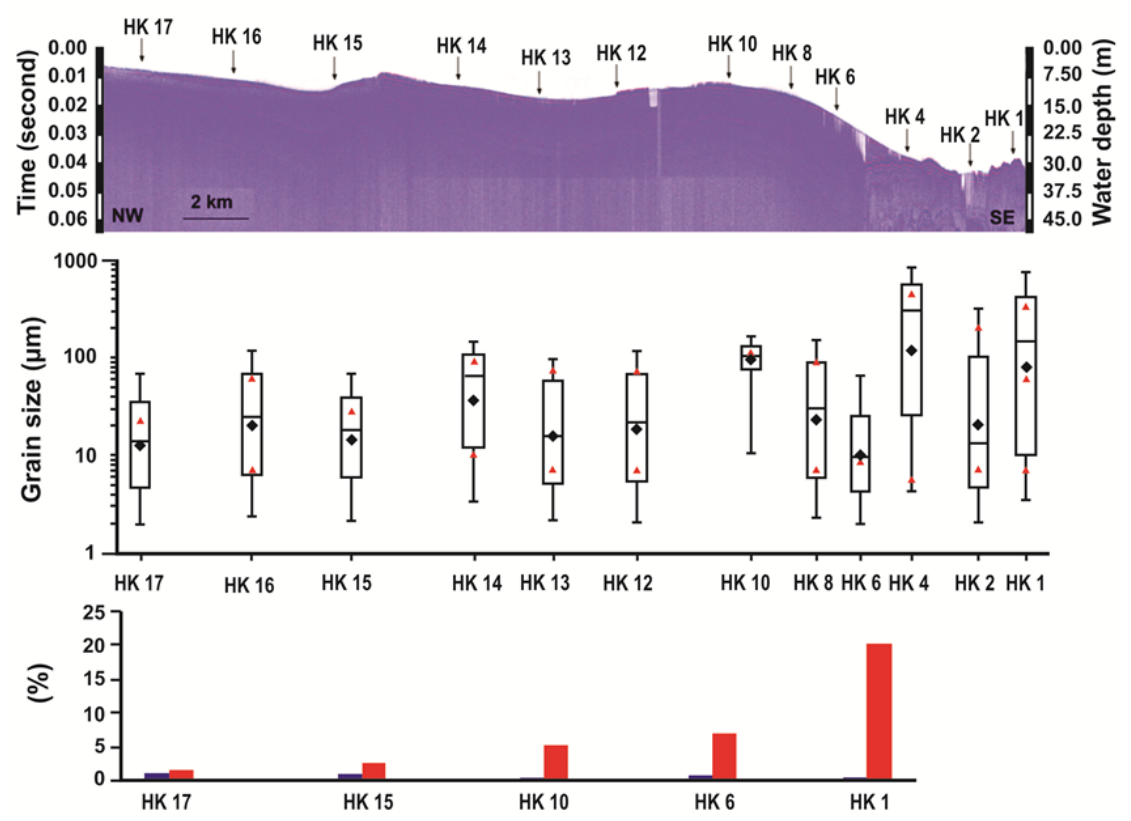

Figure 9. Variation of grain-size parameters along transect 06

Transect 7 was located southward of the $\mathrm{Ca}$ Mau Peninsula. The sediment on the topset ranged from medium silt to coarse silt. Some areas showed bimodal distribution pattern, as fine silt to very fine sand. The sediments were finer down the foreset and the grain-size distribution was less skewed, better sorted, forming single mode of fine silt $(5-8 \mu \mathrm{m})$. The sediments on the adjacent shelf was poorly sorted with major mode coarser than $400 \mu \mathrm{m}$ and another fine mode of fine silt $(5-8 \mu \mathrm{m})$ that are observed in the grain size distribution curves. The coarser mode was suggested to be resulted from carbonate materials or relict materials while the finer mode was likely generated by the Mekong River source (Figure 10).

Transect 08 was located westward of the $\mathrm{Ca}$ Mau Peninsular. The sediments on this transect were the finest in comparison to all other transects (Figure 11). The sediments on the foreset were uniform, commonly containing fine silt, indicating low hydrodynamic energy and steady conditions for sedimentation and a further distance of over $300 \mathrm{~km}$ from the sediment sources of the Mekong River mouths.

The data of all the samples in the study area were used for interpolation to generate the sediment distribution maps around the Mekong River delta. The distribution map of sand fraction and grain size parameters (mean, median, mode 1) were generated to determine the trend of sediment transport and deposition in the subaqueous Mekong delta. This determination is applied for the sediment flow from the Mekong River mouths. However, the grain-size parameters revealed a number of samples containing a considerable amount of carbonate sediments and relict sediments on the adjacent shelf that made a less distinguishable trend of sediment transport and deposition. Therefore, 16 of total 238 samples were excluded from the computation. The distribution pattern of sediment grain sizes showed that: the mean sediment grain size $>60 \mu \mathrm{m}$ distributed in front of the Hau River mouths and tended to be finer in the coastal waters off Bac Lieu coast. The mean sediment 
Vietnam Journal of Earth Sciences, 39(3), 193-209

grain size $>40 \mu \mathrm{m}$ distributed around Ganh Hao River mouth and tended to be coarser in the transitional area from pro-delta to the adjacent shelf. The mean sediment grain size was generally $<60 \mu \mathrm{m}$ in the areas from
Bo De to Ca Mau Peninsula. The tendency of mean sediment grain sizes showed that fine sediments were dominant in southwestward and western part of $\mathrm{Ca}$ Mau Peninsula (Figure 12).

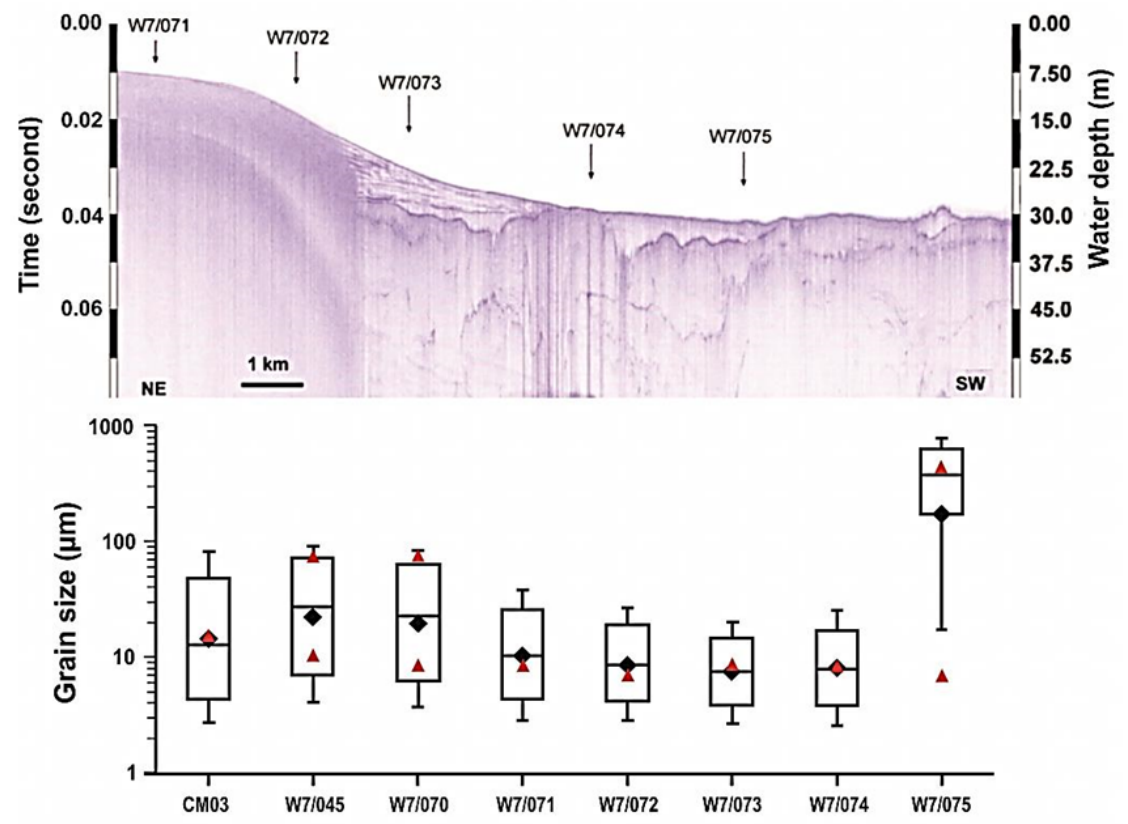

Figure 10. Variation of grain-size parameters along transect 07

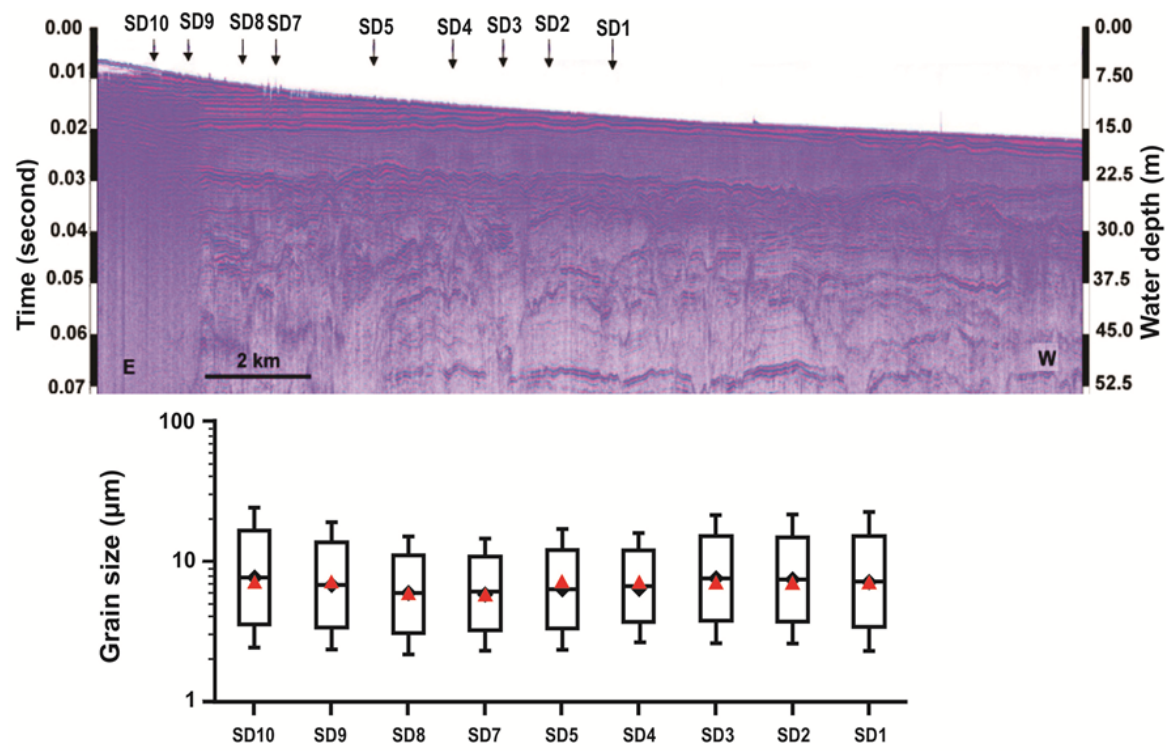

Figure 11. Variation of grain-size parameters along transect 08 
Nguyen Trung Thanh, et al./Vietnam Journal of Earth Sciences 39 (2017)

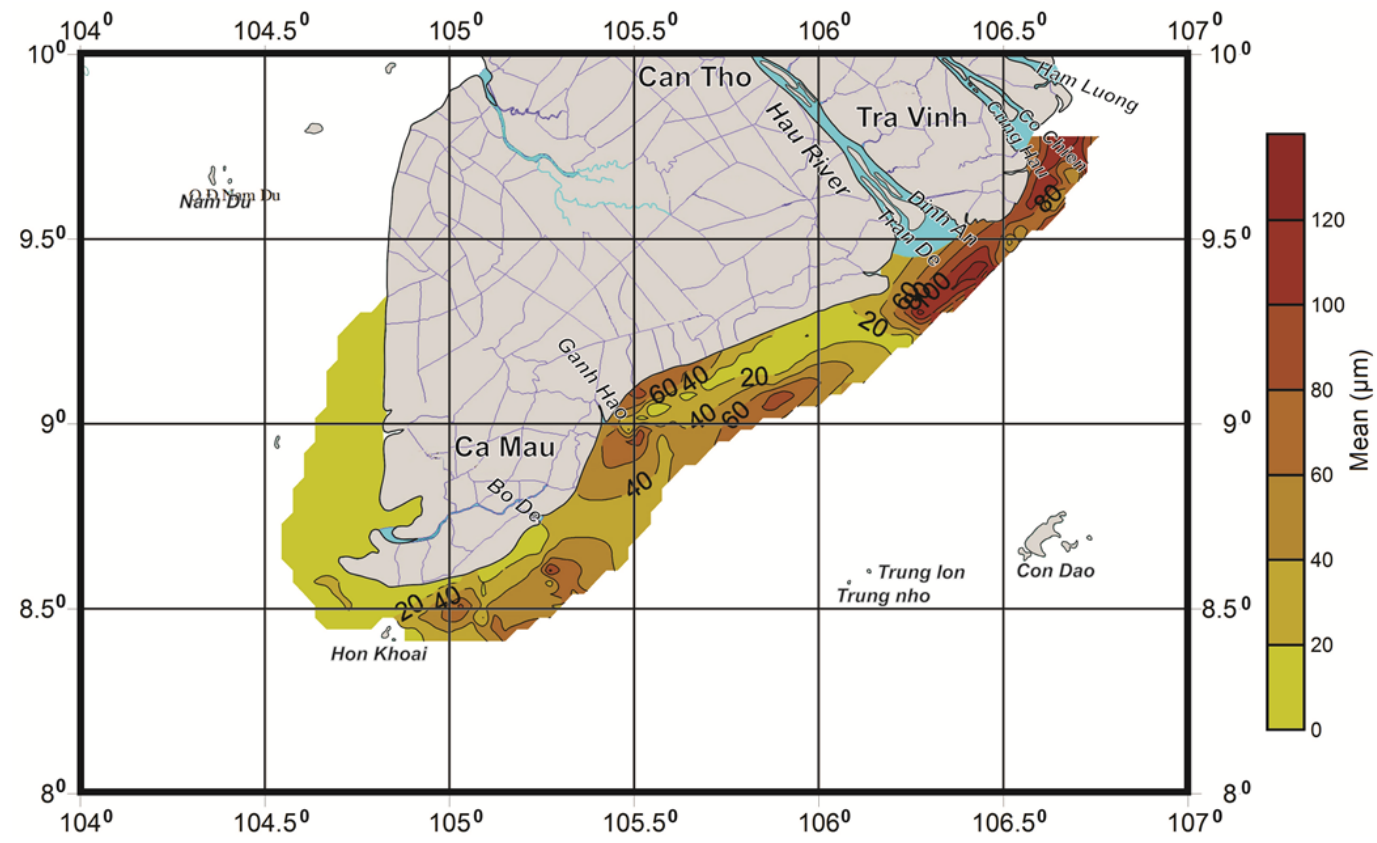

Figure 12. Distribution of mean sediment grain size $(\mu \mathrm{m})$

The median sediment grain sizes were applied widely in calculations of sediment transport. Therefore, the map of median sediment grain size distribution could use to interpret hydrodynamics for the study area. The median sediment grain size $>90 \mu \mathrm{m}$ distributed in front of the Hau River mouths and was finer toward the Ganh Hao River mouth (Figure 13). Around the Ganh Hao River mouth, the median grain size varied between $30-90$ $\mu \mathrm{m}$ and tended to be finer in the southwestward and western part of Ca Mau Peninsula.

Almost sediments were characterized by two or three distribution modes in the transitional zone from foreset to the adjacent inner shelf or sometimes from topset to foreset regions (Figure 14). Based on the distribution map, we selected the mode 1 for interpolation, because the mode 1 was dominant over mode 2 and mode 3 and half of sediment samples had only one mode (mode 1). Mode 1 of sediment grain sizes $>45 \mu \mathrm{m}$ mainly distributed in front of Hau River mouths and from Ganh Hao toward the Hon Khoai Island, while mode 1 of sediment grain sizes $>25 \mu \mathrm{m}$ was dominant in the western part of the $\mathrm{Ca} \mathrm{Mau}$ Peninsula and southeastern part of Bac Lieu Province (Figure 15). The sand fraction was dominant, being greater than $40-60 \%$ in the front of the Hau River mouths (Figure 16). The sand fraction $>30 \%$ scatted in several places from Ganh Hao River Mouth to the Hon Khoai Island. In contrast, the sand fraction was less than $30 \%$ or even $<15 \%$ from Hon Khoai to western part of the $\mathrm{Ca}$ Mau Peninsula (Figure16). 
Vietnam Journal of Earth Sciences, 39(3), 193-209

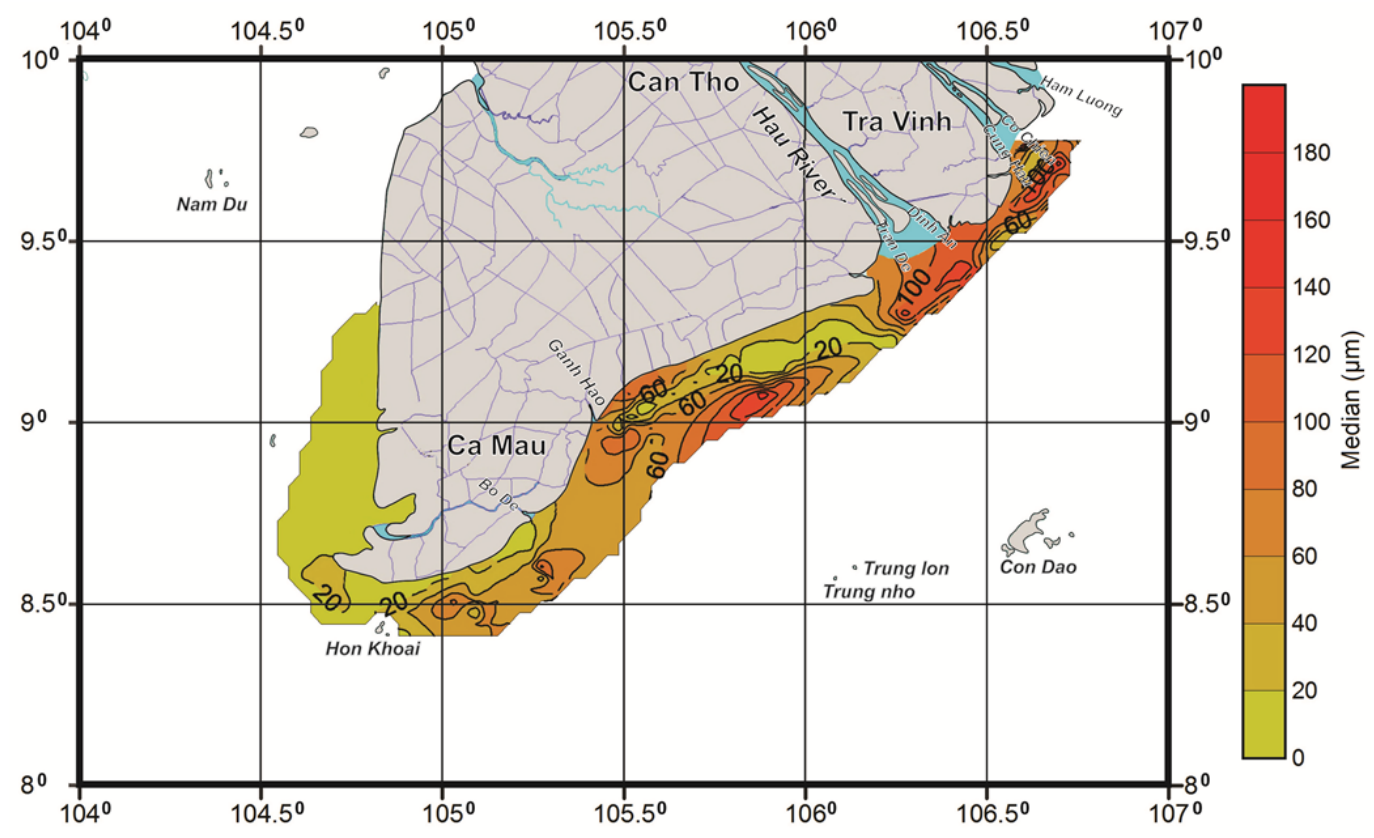

Figure 13. Distribution of median sediment grain size $(\mu \mathrm{m})$

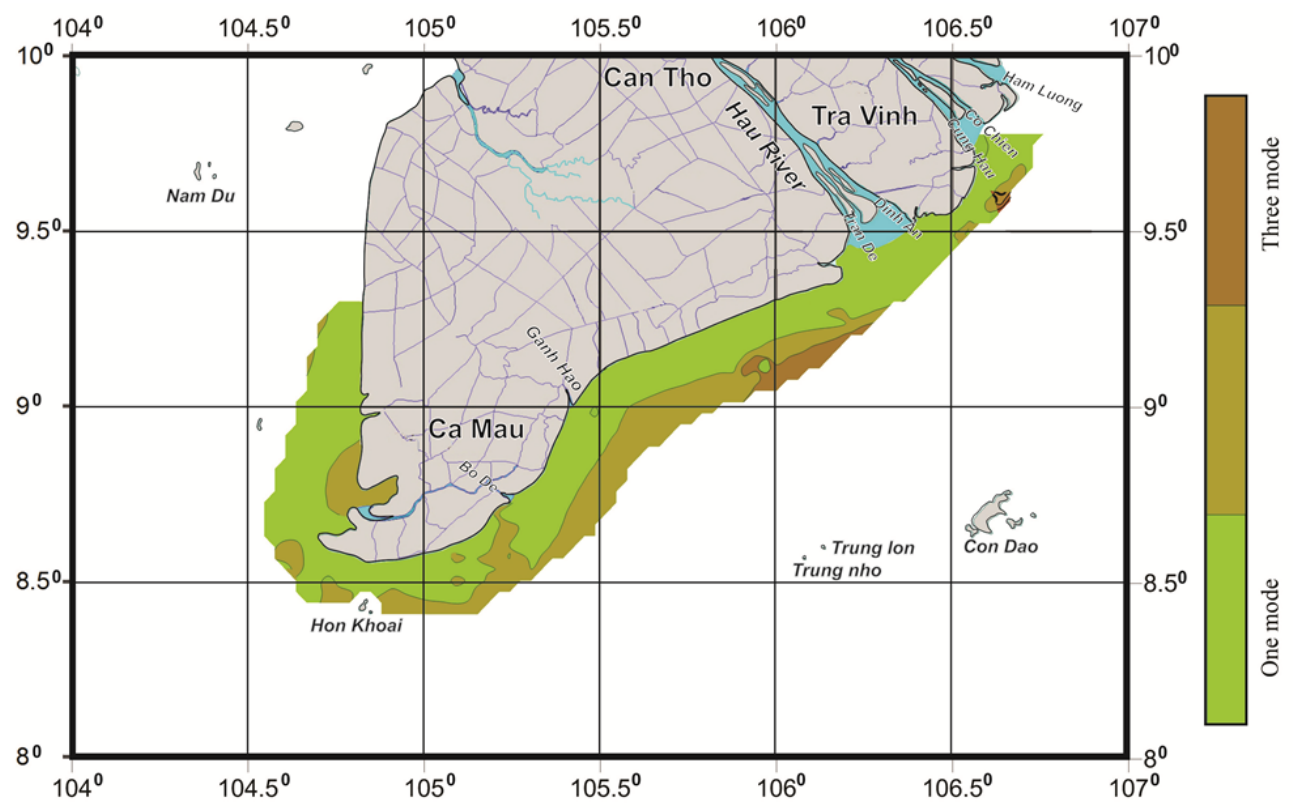

Figure 14. Distribution of mode number 
Nguyen Trung Thanh, et al./Vietnam Journal of Earth Sciences 39 (2017)

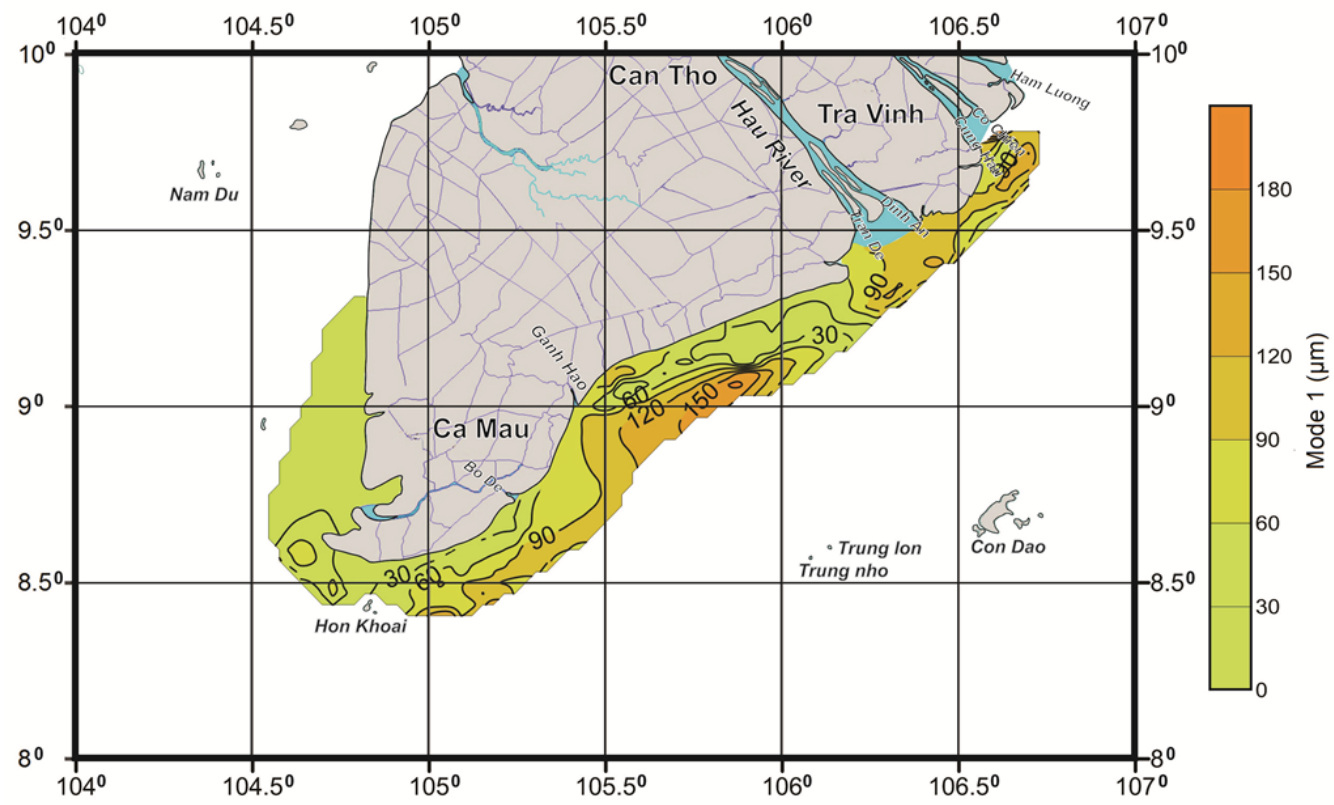

Figure 15. Distribution of grain size mode $1(\mu \mathrm{m})$

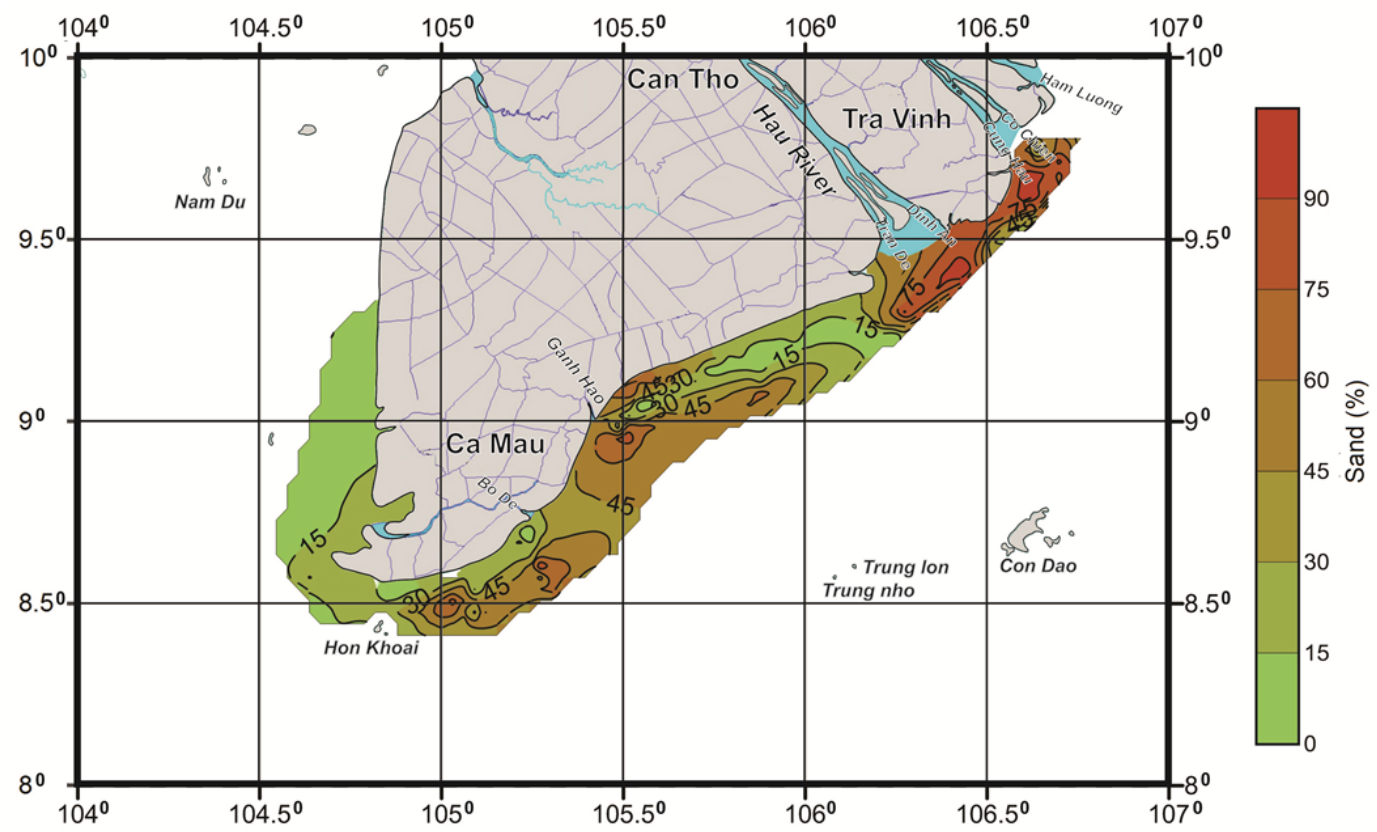

Figure 16. Distribution of sand fraction (\%)

Early studies on sediment grain-size revealed that the mean grain size particles de- creased in the direction of transport (Pettijohn and Ridge, 1932; Mothersill, 1969). In this 
Vietnam Journal of Earth Sciences, 39(3), 193-209

case, if we assume the Mekong River was a major source of the subaqueous sediments, the sediment grain-sizes would decrease southwestward due to the dominance of the northeast monsoon in sediment transport (Xue et al., 2012). However, this trend was not clear from Hau River mouths to Ganh Hao, due to the occurrence of finer sediments. This suggested that the sand sediments transported from the Mekong River distributaries to the shallow coastal waters during high flow mainly deposited around their mouths. Therefore, the shelf currents driven by waves and northeast monsoon were only able to transport resuspended sediments toward the Southwest from the Mekong River mouths to the Ca Mau Peninsula.

The sand sediments observed on the subaqueous delta between the Ganh Hao River mouth and the Hon Khoai Island could be resulted from the process of coastal erosion. Cross-shore currents (e.g., rip currents) and tidal currents could deliver sediments seaward. The morphological characteristics of transects 03, 04, 05 and 06 showed an evidence of seabed erosion in the subaqueous delta. Besides, the coastal erosion from Ganh Hao to the Ca Mau Cape has been observed for over a decade with the highest intensity along the coastline of the Mekong River Delta (Anthony et al., 2015) and predicted from modeling data (Hein et al., 2013). The sand sediments were transported southwestward by longshore currents to form two sand ridges that run parallel to the shoreline. The sediment grain size parameters showed that sediments become finer with transport direction from the Ganh Hao to the western area of the Ca Mau Peninsula. The sediment dispersal pathways are shown in Figure 17. Sand deposition occurred mainly in front of the Mekong river mouths while mud fraction mainly deposited in the coastal water along the coast of Bac Lieu Province and from Hon Khoai Island to the west part of the Ca Mau Peninsular. Both sand and mud depositions were found in the area between Ganh Hao and Hon Khoai Island.

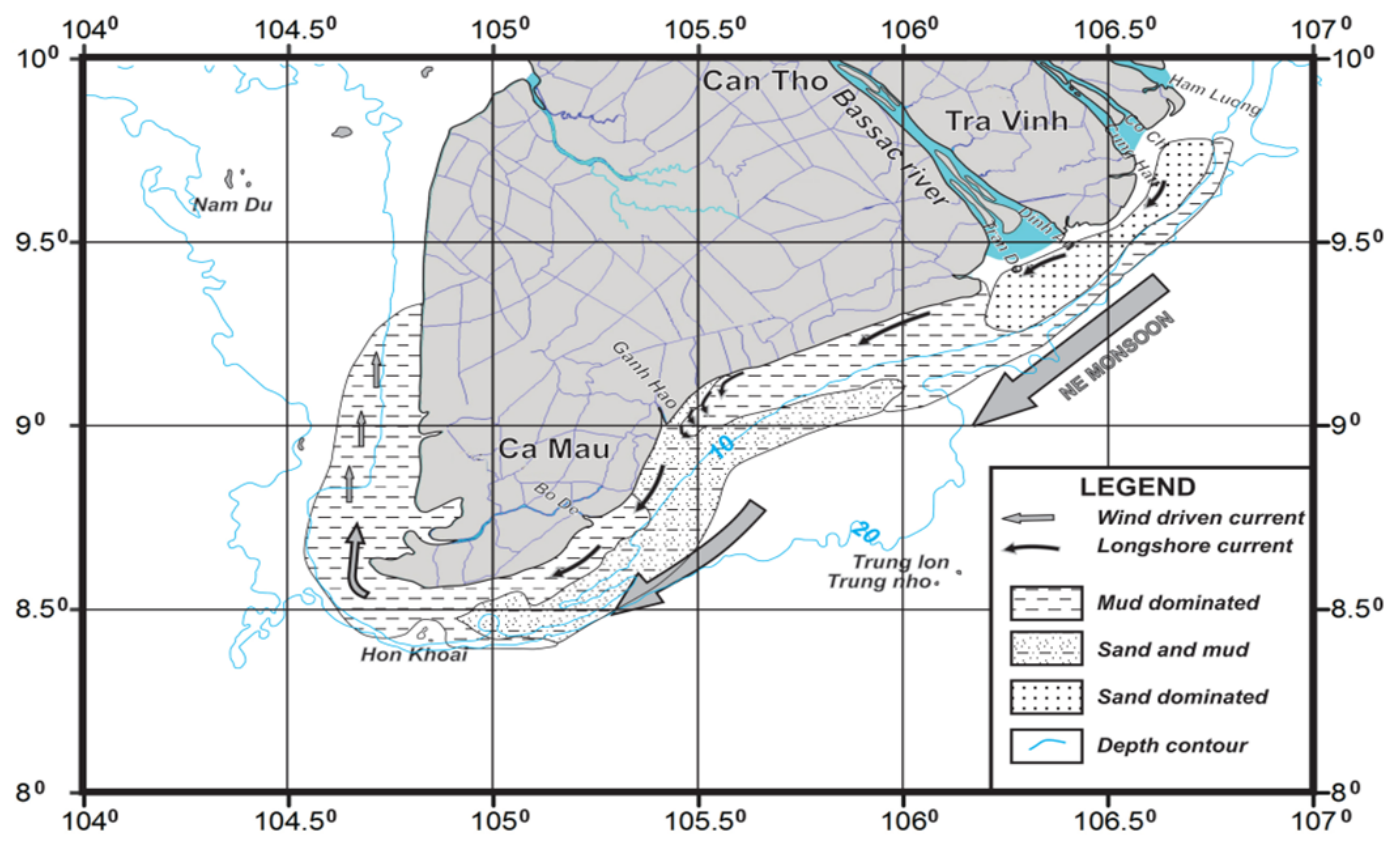

Figure 17. Sediment deposition and transport pathways under the influence of northeast monsoon 


\section{Conclusions}

The variation of sediment grain-size parameters from eight transects in the subaqueous Mekong Delta showed that a decreasing trend of sediment grain size was observed from seaward across the clinoform topset and foreset. Coarser sediments were abruptly dominant on the adjacent shelf, due to the less influence of modern sediments from the Mekong River and contained a greater fraction of carbonate shell fragments and early relict Holocene sediments. Characteristics of surface sediments on the subaqueous delta varied with sub-environments and were controlled by the clinoform configuration and hydrodynamic regimes in different water depths, presenting of delta coastal erosion, and proximity to Mekong distributaries. Generally, sediments were dispersed southwestward on the Mekong subaqueous delta that was well described in the distribution maps of grain-size parameters and sand content. This study demonstrated the importance of the northeast monsoon in the winter, which dominates over the southwest monsoon in the summer time. Fine sediments were transported from the Mekong River mouths to the Ca Mau Pennisula as suspended load during the northeast monsoon.

\section{Acknowledgments}

The authors would like to thank to Ministry of Science and Technology (MOST) in Vietnam and US Office of Research Navy Global (ORNG) with the grant 12026593 for supporting Vietnam-US collaboration. Nguyen Trung Thanh appreciates Vietnam Academy of Science and Technology (VAST) that supported this research with the grant VAST0601/16-17. The authors would like to thank crew and colleagues who participated in the cruises in the coastal waters around the Mekong River Delta.

\section{References}

Anthony J.E., Brunier G., Besset M., Goichot M., Dusouillez P., Nguyen V.L., 2015. Linking repid erosion of the Mekong River delta to human activities. Scientific Reports, 1-12.

Blott S.J and Pye K., 2001. Gradistat: a grain size distrubution and statistics package for the analysis of unconsolidated sediments, Technical Communication. Earth Surface Processes and Landforms, 26, 1237-1248.

Dung B.V., Schimanski A., Stattegger K., Phach P.V., Tiep N.T., Hai N.T., Thanh N.T., Phi T.T., 2009. Sandwaves on the Southeast Vietnam Shelf recorded by high resolution seismic profiles: formation and mechanism. Front. Earth Sci. China, 3(1), 9-20.

Dung B.V., Stattegger K., Unverricht D., Phach P.V., Thanh N.T., 2013. Late Pleistocene-Holocene seismic stratigraphy of the Southeast Vietnam Shelf. Global and Planetary Change 110, 156-169.

Hein H., Hein B., Pohlmann T., 2013. Recent dynamics in the region of Mekong water influence. Global and Planetary Change, 110, 183-194.

Folk R.L. and Ward W.C., 1957. Brazos River bar: a study in the significance of grain size parameters. Journal of Sedimentary Petrology, 27, 3-26.

Liu S., Lu P., Liu D., Jin P and Wang W., 2009. Pinpointing source and measuring the lengths of the principal rivers of the world. International Journal of Digital Earth, 2, 80-87. doi:10.1080/17538940902746082.

Mothersill J., 1969. A grain size analysis of longshore bars and troughs, Lake Superior, Ontario. Journal of Sedimentary Petrology, 39, 1317-1324.

Milliman J.D. and Meade R.H., 1983. World-wide delivery of river sediments to the ocean. Journal of Geology, 91, 1-21.

Milliman J.D., Syvistski J.P.M., 1982. Geomorphic/tectonic control of sediment discharge to the oceans: the importance of small mountain rivers. Journal of Geology, 100, 525-544.

Pettijohn F.G., Ridge J.D., 1932. A textural variation series of beach sands from Cedar Point, Ohio, Journal of Sedimentary Petrology, 2, 76-88.

Ninh P.V. (Ed.)., 2003. South China Sea Monograph, Vol II-Meteorology, Marine Hydrology and Hydrodynamics, Hanoi National University Publisher., 565p, Hanoi, (in Vietnamese). 
Vietnam Journal of Earth Sciences, 39(3), 193-209

Nowacki D.J., Ogston A.S., Nittrouer C.A., Fricke A.T., and Van Pham Dang Tri, 2015. Sediment dynamics in the lower Mekong River: Transition from tidal river to estuary. J. Geophys, Res, Oceans, 120, 63636383, doi:10.1002/2015JC010754.

Kubicki A., 2008. Large and very large subaqueous delta dunes on the continental shelf off southern Vietnam, South China Sea. Geo-Mar. Lett, 28, 229238. Doi:10.1007/s00367-008-0103-9.

Sibson R., 1981. A brief description of natural neighbor interpolation, in V. Barnett, ed., Interpreting Multivariate Data: John Wiley \& Sons, 21-36.

Stattegger K., Tjallingii R., Saito Y., Michelli M., Thanh N.T., Wetzel A., 2013. Mid to late Holocene sealevel reconstruction of Southeast Vietnam using beachrock and beach-ridge deposits. Global and Planetary Change, 110, 214-222.

Szczuciński W., Jagodziński R., Hanebuth T.J.J., Stattegger K., Wetzel A., Mitręga M., Unverricht D., Phach P.V., 2013. Modern sedimentation and sediment dispersal pattern on the continental shelf off the Mekong River delta, South China Sea. Global and Planetary Change, 110, 195-213.

Ta T.K.O., Nguyen V.L., Kobayashi I., Tateishi M and Saito Y., 2001. Late Pleistocene-Holocene stratigraphy and delta progradation, the Mekong River delta, South Vietnam. Gondwana Research, 4(4), 779.

Ta T.K.O., Nguyen V.L., Tateishi M., Kobayashi I., Saito Y., Nakamura T., 2002a. Sediment facies and Late Holocene progradation of the Mekong River Delta in Bentre Province, southern Vietnam: an example of evolution from a tide-dominated to a tideand wave-dominated delta. Sedimentary Geology, 152, 313-325. Doi 10.1007/s11707-009-0002-z.

Ta T.K.O, Nguyen V.L., Tateishi M., Kobayashi I., Tanabe S., Saito Y., 2002b. Holocene delta evolution and sediment discharge of the Mekong River, southern Vietnam: Quaternary Science Reviews, 21, 1807-1819.

Tamura T., Saito Y., Sieng S., Ben B., Kong M., Choup S., Tsukawaki S., 2007. Depositional facies and radiocarbon ages of a drill core from the Mekong River lowland near Phnom Penh, Cambodia: evidence for tidal sedimentation at the time of Holo- cene maximum flooding. J. Asian Earth Sci., 29, 585-592.

Tamura T., Saito Y., Sieng S., Ben B., Kong M., Sim I., Choup S., Akiba F., 2009. Initiation of the Mekong River delta at $8 \mathrm{ka}$ : evidence from the sedimentary succession in the Cambodian lowland. Quaternary Science Review, 28, 327-344.

Thanh N.T., Phach P.V., Dung B.V., Statteger K., Anh L.D., Anh P.T., 2014. Sedimentary evolution on the inner shelf adjacent to the Camau Pennisular in the lastest Late Pleistocene-Holocene. Journal of Marine Science and Technology (in Vietnamese).

Tjallingii R., Stattegger K., Wetzel A., Phach P.V., 2010. Infilling and flooding of the Mekong River incised valley during deglacial sea-level rise. Quaternary Science Reviews, 29, 1432-1444.

Xue Z, Liu J.P., DeMaster D., Nguyen V.L., Ta T.K.O., 2010. Late Holocene Evolution of the Mekong Subaqueous Delta, Southern Vietnam. Marine Geology, 269, 46-60.

Xue Z., Liu J.P., Ge Q., 2011. Changes in hydrology and sediment delivery of the Mekong River in the last 50 years: connection to damming, monsoon, and ENSO. Earth Surf. Process. Landforms, 36, 296-308.

Xue Z., He R., Liu J.P., Warner J.C., 2012. Modeling transport and deposition of the Mekong River sediment. Continental Shelf Research, 37, 66-78.

Xue Z., Liu J.P., DeMaster D., Leithold E.L., Wan S., Ge Q., Nguyen V.L., Ta T.K.O., 2014. Sedimentary processes on the Mekong subaqueous delta: Clay mineral and geochemical analysis. Journal of Asian Earth Sciences, 79, 520-528.

Unverricht D., Szczuciński W., Statteger K., Jagodziński R., Le X.T., Kwong L.L.W., 2013. Modern sedimentation and morphology of the subaqueous Mekong Delta, Southern Vietnam. Global and Planetary Change, 110, 223-235.

Wolanski E., Nguyen N.H., Spagnol S., 1998. Sediment dynamics during low flow conditions in the Mekong River Estuary, Vietnam. Journal of Coastal Research, 14, 472-482.

Wolanski E., Ngoc Huan N., Trong Dao L., Huu Nhan N., Ngoc Thuy N., 1996. Fine sediment dynamics in the Mekong River Estuary, Vietnam Estuar. Coast. Shelf Sci, 43, 565-582. 